\title{
Efficacies of Carbon-Based Adsorbents for Carbon Dioxide Capture
}

\author{
Tasmina Khandaker ${ }^{1}$, Muhammad Sarwar Hossain ${ }^{1,2}$, Palash Kumar Dhar ${ }^{2}$ D, \\ Md. Saifur Rahman ${ }^{3}$, Md. Ashraf Hossain ${ }^{4, *}$ and Mohammad Boshir Ahmed ${ }^{3, *(D)}$ \\ 1 Department of Chemistry, Sogang University, Seoul 04107, Korea; tasmina@sogang.ac.kr (T.K.); \\ sarwar@sogang.ac.kr (M.S.H.) \\ 2 Chemistry Discipline, Khulna University, Khulna 9208, Bangladesh; palashdhar@ku.ac.bd \\ 3 School of Materials Science and Engineering, Gwangju Institute of Science and Technology, \\ Gwangju 500-712, Korea; saifurrahman@gist.ac.kr \\ 4 Department of Materials Science and Engineering, Korea University, Seoul 02841, Korea \\ * Correspondence: ashraf3521@korea.ac.kr (M.A.H.); Mohammad.Ahmed@gist.ac.kr (M.B.A.)
}

Received: 8 April 2020; Accepted: 27 May 2020; Published: 30 May 2020

\begin{abstract}
Carbon dioxide $\left(\mathrm{CO}_{2}\right)$, a major greenhouse gas, capture has recently become a crucial technological solution to reduce atmospheric emissions from fossil fuel burning. Thereafter, many efforts have been put forwarded to reduce the burden on climate change by capturing and separating $\mathrm{CO}_{2}$, especially from larger power plants and from the air through the utilization of different technologies (e.g., membrane, absorption, microbial, cryogenic, chemical looping, and so on). Those technologies have often suffered from high operating costs and huge energy consumption. On the right side, physical process, such as adsorption, is a cost-effective process, which has been widely used to adsorb different contaminants, including $\mathrm{CO}_{2}$. Henceforth, this review covered the overall efficacies of $\mathrm{CO}_{2}$ adsorption from air at $196 \mathrm{~K}$ to $343 \mathrm{~K}$ and different pressures by the carbon-based materials (CBMs). Subsequently, we also addressed the associated challenges and future opportunities for CBMs. According to this review, the efficacies of various $\mathrm{CBMs}_{\text {for }} \mathrm{CO}_{2}$ adsorption have followed the order of carbon nanomaterials (i.e., graphene, graphene oxides, carbon nanotubes, and their composites) $<$ mesoporous -microporous or hierarchical porous carbons $<$ biochar and activated biochar $<$ activated carbons.
\end{abstract}

Keywords: $\mathrm{CO}_{2}$ capture; activated carbon; carbon nanomaterials; adsorption; surface area

\section{Introduction}

Fossil fuels supply more than $98 \%$ of the world's energy demands [1]. Due to the burning of fossil fuels in industrial activities, the concentration of $\mathrm{CO}_{2}$ has been increasing in the atmosphere significantly [2]. For example, $\mathrm{CO}_{2}$ concentration hits up to $415.26 \mathrm{ppm}$ at the Mauna Loa Observatory in Hawaii [3]. It is estimated that, in 2050, the atmospheric $\mathrm{CO}_{2}$ concentration will reach up to $550 \mathrm{ppm}$ [3]. Therefore, the increased concentration of $\mathrm{CO}_{2}$ in the atmosphere causes global warming and significant environmental problems [3-5]. Hence, there is a great urgency to reduce the $\mathrm{CO}_{2}$ level from the atmosphere through the utilization of different technologies. The intergovernmental panel on climate change has recommended three fundamental steps for carbon capture and storage for combating carbon dioxide emissions. These involve (i) separation through capture, (ii) transportation, and (iii) storage of $\mathrm{CO}_{2}[6]$. Although enough progress has been made on transportation and storage of $\mathrm{CO}_{2}$, progress is still going on the capture of $\mathrm{CO}_{2}$ through different processes [7]. Membrane separation techniques have been utilized for the capture of $\mathrm{CO}_{2}$ at low pressure. However, these kind of technologies often suffers from high operating costs, and they are non-energy efficient to compress the 
feed gas [8]. Technologies for the removal of $\mathrm{CO}_{2}$ from ambient air have been recently demonstrated using different solid or liquid sorbents, which can contribute to "negative carbon emission", although there remains much room for their improvements $[9,10]$. On the other hand, porous-based materials are very promising materials to adsorb $\mathrm{CO}_{2}$. Hence, compared to the liquid adsorption-based technology (such as amine-based adsorption technology), $\mathrm{CO}_{2}$ capture via solid-state materials (e.g., adsorption technology) is very cost-effective, easy to design, has a functional surface, hydrophobicity, need low energy consumption, simple operation, and easy regeneration of adsorbents [11-15]. Solid adsorbents are alkaline metal oxides and hydroxides, zeolite, metal-organic frameworks, porous polymers, and carbon-based materials (CBMs), such as activated carbon, biochar, nanocarbons (carbon nanotubes (CNTs) and graphene), mesoporous, and microporous carbons, and so on. Among them, CBMs have great potential in the capture of $\mathrm{CO}_{2}$ due to their high surface area, well-defined porosities, larger pore volume, chemical stability, and easy handling [3,11-19].

Scheme 1 demonstrates a brief summary of CBMs, which are used for the adsorption of $\mathrm{CO}_{2}$. Although there are many reviews on $\mathrm{CO}_{2}$ capture, however, to our best knowledge, none of them has discussed the overall efficacy of $\mathrm{CMBs}$ for adsorption of $\mathrm{CO}_{2}$. Therefore, the main objective of this review was to demonstrate the comparative analysis of the efficacies of different $\mathrm{CBMs}$ for $\mathrm{CO}_{2}$ adsorption from the air at different temperatures and pressures. The subsequent objective of this review was to provide an overview of the performance of CBMs together with the major associated challenges and future opportunities for the potential applications of $\mathrm{CBMs}$ as $\mathrm{CO}_{2}$ adsorbents. Hence, we believed that this review would be very helpful for the different researchers and stockholders for the understanding of the recent trends of $\mathrm{CBMs}$ performances for $\mathrm{CO}_{2}$ capture through adsorption technology.

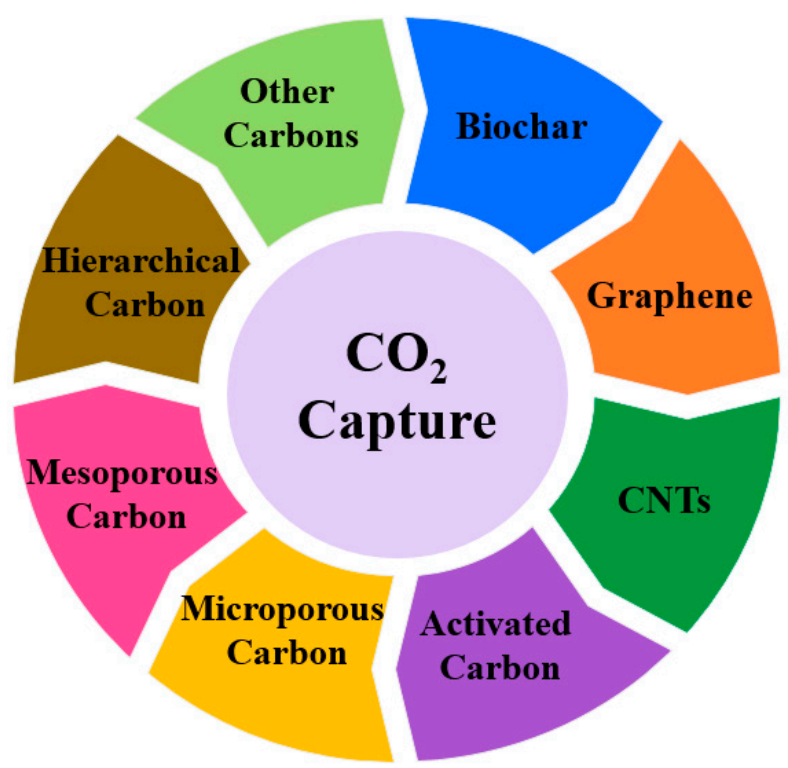

Scheme 1. CBMs (carbon-based materials) for $\mathrm{CO}_{2}$ capture through adsorption technology.

\section{Efficacy of $\mathrm{CBMs}$ for $\mathrm{CO}_{2}$ Capture}

CBMs are considered as the top performance material for $\mathrm{CO}_{2}$ adsorption from the air [15]. CBMs have specific properties, which are highly required for efficient $\mathrm{CO}_{2}$ capture. There are many types of carbon-based adsorbents, but they can be broadly classified as biochar, nanocarbons materials (e.g., graphene, CNTs, nanocarbons), activated carbons (ACs), different microporous, mesoporous, and hierarchical carbons with or without doping with other inorganic, organics, metal components, or metal atoms, and so on. All of these CBMs have a significant surface area, pore density, volume, pore size, high stability, and sustainability properties, which are prime requirements for efficient $\mathrm{CO}_{2}$ capture. Therefore, this review has covered the performances of biochar, different nanomaterials, such as graphene, graphene oxides, and carbon nanotubes (CNTs), ACs, microporous, mesoporous, and 
hierarchical porous carbon materials together with their composites. The following subsections have addressed $\mathrm{CO}_{2}$ capture efficacies using those CBMs.

\subsection{Biochar for $\mathrm{CO}_{2}$ Capture}

Recently, among various adsorptive materials (e.g., AC, graphene, carbon fibers, etc.), biochar has gained considerable attention as an eco-friendly and cost-effective material for $\mathrm{CO}_{2}$ capture and sequestration, as catalysts, as greenhouse gas capturing material, as water treatment and, as soil remediation materials [20-22]. Biochar is a carbon-rich material, which is prepared from natural resources having high surface area, hydrophobic nature, and easy regeneration capability [23]. These properties make the biochar an attractive material for the researcher's various applications [24,25]. Biochar can be synthesized from cheap and easily available biomass feedstocks and wastes from different industries (e.g., dairy manure, forestry, agricultural) and many other bio-wastes [26-28]. Biomass resources are composed of $\mathrm{C}, \mathrm{O}, \mathrm{H}$ structures and some of the inorganic materials in their complex matrix together with different heteroatoms (e.g., N, P, or S) [21,29]. However, the quality and yield of biochar depend on several parameters, such as feedstock material and operational conditions.

Biochar can be prepared through different processes, such as gasification (where different biochar, gaseous fuel, such as syngas, and tar (oil) are produced); torrefaction (where biomass is thermally treated for a short period at low-temperature sally 473-573 K); hydrothermal carbonization (where biochar is produced in the presence of water, low oxygen content, high pressure, usually 14-22 MPa, and low temperature at 393-573 K); pyrolysis process (where biomass is thermally converted into its basic graphitic structure at 473_1473 $\mathrm{K}$ in a limited or inert atmosphere) [30-32]. Figure 1 shows a simple overview of biochar production from biomass using different thermochemical processes. Hence, the porous biochar is produced [24,33,34].

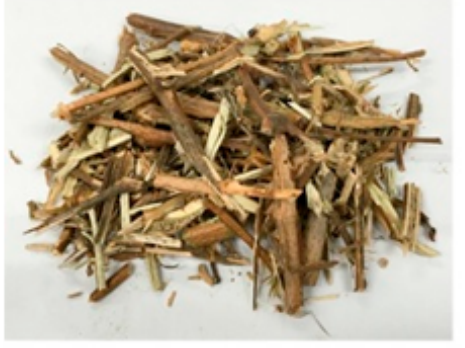

Biomass

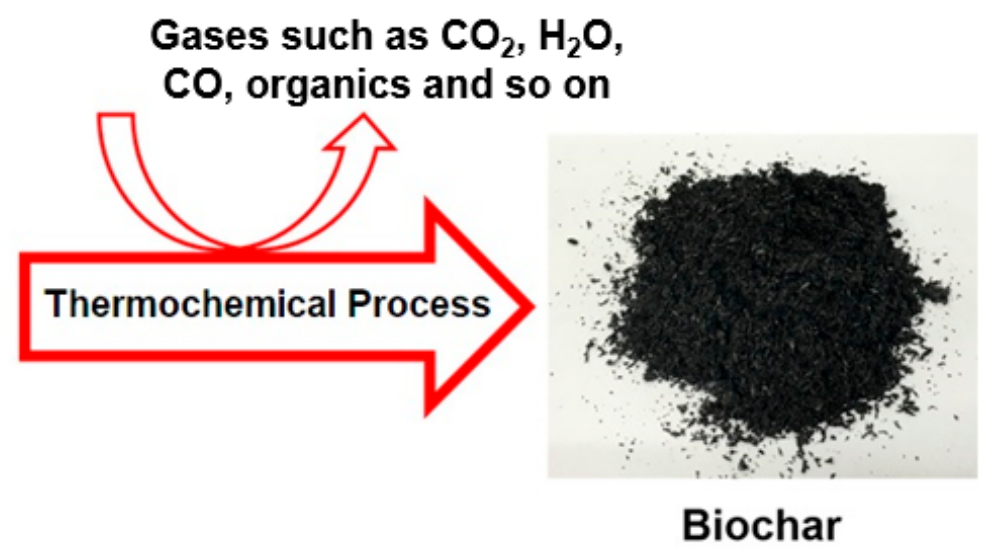

Figure 1. A general overview of biochar production from different biomasses.

Owing to the unique structure and surface properties of biochar, it can act as an excellent adsorbent for the capture of several gases. In a study, Mohd et al. [35] reported that adsorption of toxic gases on biochar surface took place mainly through the physisorption process. The surface of biochar contains macro and micropores, which act as a storage place for gas molecules [35]. Table 1 shows the $\mathrm{CO}_{2}$ intake capacity of biochar at 1 bar atmospheric pressure and two different temperatures. It is clear from the table that chemically activated biochar prepared from Vine shoots were capable of adsorbing a higher amount of $\mathrm{CO}_{2}(6.08 \mathrm{mmol} / \mathrm{g}$ at $1 \mathrm{bar}$ and $273 \mathrm{~K})$ compared to physically activated biochar $(4.07 \mathrm{mmol} / \mathrm{g}$ at 1 bar and $273 \mathrm{~K}$ ) [36,37]. In another study, Ello et al. [37] prepared biochar and biochar activated with $\mathrm{KOH}$ at $1133 \mathrm{~K}$ for $1 \mathrm{~h}$ from Africa palm shells. They reported higher $\mathrm{CO}_{2}$ adsorption capacities $\left(6.3 \mathrm{mmol} / \mathrm{g}\right.$ at $273 \mathrm{~K}$ and $4.4 \mathrm{mmol} / \mathrm{g}$ at $298 \mathrm{~K}$ and $1 \mathrm{bar}$, respectively). On the other hand, different $\mathrm{CO}_{2}$ intake capacities were also reported for chemically activated biochars from rice husk (3.71 mmol/g) [38], pine nutshell $(5.0 \mathrm{mmol} / \mathrm{g})$ [39], wheat flour $(3.48 \mathrm{mmol} / \mathrm{g})$ [40], vine shoots $(2.46 \mathrm{mmol} / \mathrm{g})$ [36], coconut 
shells (4.23 mmol/g) [11], Jujun grass (hydrochar, $4.9 \mathrm{mmol} / \mathrm{g}$ ) [41], and Camellia Japonica (Hydrochar, $5.0 \mathrm{mmol} / \mathrm{g}$ ) [41] at $298 \mathrm{~K}$ and 1 bar pressure. Moreover, single-step pyrolysis and activation of various biomasses to produce biochar and activated biochar were also reported by Serafin et al. [42]. They found that $\mathrm{CO}_{2}$ adsorption capacities of pomegranate peels, carrot peels, and fern leaves were 4.00, 4.18, and $4.12 \mathrm{mmol} / \mathrm{g}$ at $298 \mathrm{~K}$, respectively, and $6.89,5.64$, and $4.52 \mathrm{mmol} / \mathrm{g}$ at $273 \mathrm{~K}$, respectively, at $1 \mathrm{bar}$. Zhang et al. [43] produced amine functional group doped activated biochar from black locust. They reported a $\mathrm{CO}_{2}$ adsorption capacity of $5.05 \mathrm{mmol} / \mathrm{g}$ at $298 \mathrm{~K}$ and 1 bar. Similarly, Rouzitalab et al. [44] used urea to synthesize amine-functionalized activated biochar from the walnut shell in the presence of $\mathrm{KOH}$, and they observed record $\mathrm{CO}_{2}$ adsorption capacity of $7.42 \mathrm{mmol} / \mathrm{g}$ at $298 \mathrm{~K}$ and 1 bar.

Table 1. $\mathrm{CO}_{2}$ capture performances by top performance biochar produced from different biomasses and at different conditions. The surface area is based on Brunauer-Emmett-Teller (BET).

\begin{tabular}{|c|c|c|c|c|c|}
\hline Biochar Derived from & $\begin{array}{l}\text { BET Surface } \\
\text { Area }\left(\mathrm{m}^{2} / \mathrm{g}\right)\end{array}$ & $\begin{array}{l}\text { Pressure } \\
\text { (Bar) }\end{array}$ & $\begin{array}{c}\text { Adsorption } \\
\text { Capacity }(\mathrm{mmol} / \mathrm{g}) \\
\text { at } 273 \mathrm{~K}\end{array}$ & $\begin{array}{c}\text { Adsorption } \\
\text { Capacity }(\mathrm{mmol} / \mathrm{g}) \\
\text { at } 298 \mathrm{~K}\end{array}$ & Reference \\
\hline Vine shoots & 767 & 1 & 4.07 & 1.58 & [36] \\
\hline Vine shoots & 1305 & 1 & 6.04 & 2.46 & [36] \\
\hline Vine shoots & 1439 & 1 & 6.08 & 1.98 & [37] \\
\hline African palm shells & 1250 & 1 & 6.3 & 4.4 & [37] \\
\hline Rice husk & 2695 & 1 & 6.24 & 3.71 & [38] \\
\hline Pine nut shells & 1486 & 1 & 7.7 & 5.00 & [39] \\
\hline Wheat flour & 1438 & 1 & 5.70 & 3.48 & [40] \\
\hline Coconut shells & 1172 & 1 & 6.04 & 4.23 & [11] \\
\hline Jujun grass & 1512 & 1 & - & 4.9 & [41] \\
\hline Jujun grass & 3144 & 1 & - & 4.1 & [41] \\
\hline Camellia Japonica & 1353 & 1 & - & 5.0 & [41] \\
\hline Camellia Japonica & 3537 & 1 & - & 2.8 & [41] \\
\hline Pomegranate peels & 585 & 1 & 6.89 & 4.00 & [42] \\
\hline Carrot peels & 1379 & 1 & 5.64 & 4.18 & [42] \\
\hline Fern leaves & 1593 & 1 & 4.52 & 4.12 & [42] \\
\hline Black locust & 2511 & 1 & - & 5.05 & [43] \\
\hline Walnut shell & 1315 & 1 & - & 7.42 & [44] \\
\hline Pine cone & 1680 & 1 & - & 4.7 & [45] \\
\hline Saw dust & 394.12 & 1 & - & 3.7 & [46] \\
\hline Mg loaded Walnut shell & 292 & 1 & - & 3.7 & [47] \\
\hline Pristiene Walnut shell & 997 & 1 & - & 3.2 & [47] \\
\hline
\end{tabular}

However, $\mathrm{CO}_{2}$ adsorption capacity can significantly vary with the changing of the surface morphology of biochar, i.e., the surface area, micropore volume, and size, together with the effects of temperature and pressure [24,42]. For example, Deng et al. [39] reported that biochar having a pore size of $0.33-0.63 \mathrm{~nm}$ played an important role in the higher $\mathrm{CO}_{2}$ adsorption. It was also reported that the control of micropores had greater importance for adsorbing high $\mathrm{CO}_{2}$ compared to surface area and total pore volume [39,42]. Figure 2 shows the presence of functional groups and porous structures (mesoporosity and microporosity) of biochar materials. Metal oxyhydroxide biochar composites have also been used to increase the adsorption capacity of biochar. For example, Lahijani et al. [47] reported that $\mathrm{Mg}$-loaded biochar showed a higher $\mathrm{CO}_{2}$ adsorption capacity $(3.7 \mathrm{mmol} / \mathrm{g})$ than that of raw biochar $(3.2 \mathrm{mmol} / \mathrm{g}$ ) at $298 \mathrm{~K}$ and $1 \mathrm{~atm}$. This phenomenon can be explained by the fact that the incorporation of metals (i.e., $\mathrm{Mg}, \mathrm{Al}, \mathrm{Ni}$, and $\mathrm{Fe}$ ) onto the biochar surface will increase basic sites on the surface of biochar, which enhances the adsorption capacity of acidic $\mathrm{CO}_{2}$ [47].

Therefore, it can be summarized that biochar and activated biochar/biochar-based adsorbents are low-cost, renewable, and promising materials for the adsorption of $\mathrm{CO}_{2}$. However, still there remain various challenges, especially which can prevent the practical and large-scale application of biochar-based adsorbents for $\mathrm{CO}_{2}$ removal, which need to be addressed. First of all, the robustness and stability of biochar-based adsorbents have not been fully demonstrated, despite the fact that high adsorption capacities and long-term cyclic operation are critical to ensure the economics and practicality of the technology [48]. Secondly, the production process should be simple, cost-efficient, and eco-friendly to develop highly efficient $\mathrm{CO}_{2}$ adsorbents. Thirdly, both physical and chemical 
modification methods have been carried out in laboratory-scale experiments. However, most studies are explorative in nature, and the effectiveness of the methods for large-scale biochar modification and application is still unclear. Finally, a new type of modified biochar should keep continuing to develop with larger surface area, well-defined porosity, together with surface functional groups, and it is also necessary to produce biochar from low-cost materials, such as agricultural wastes.

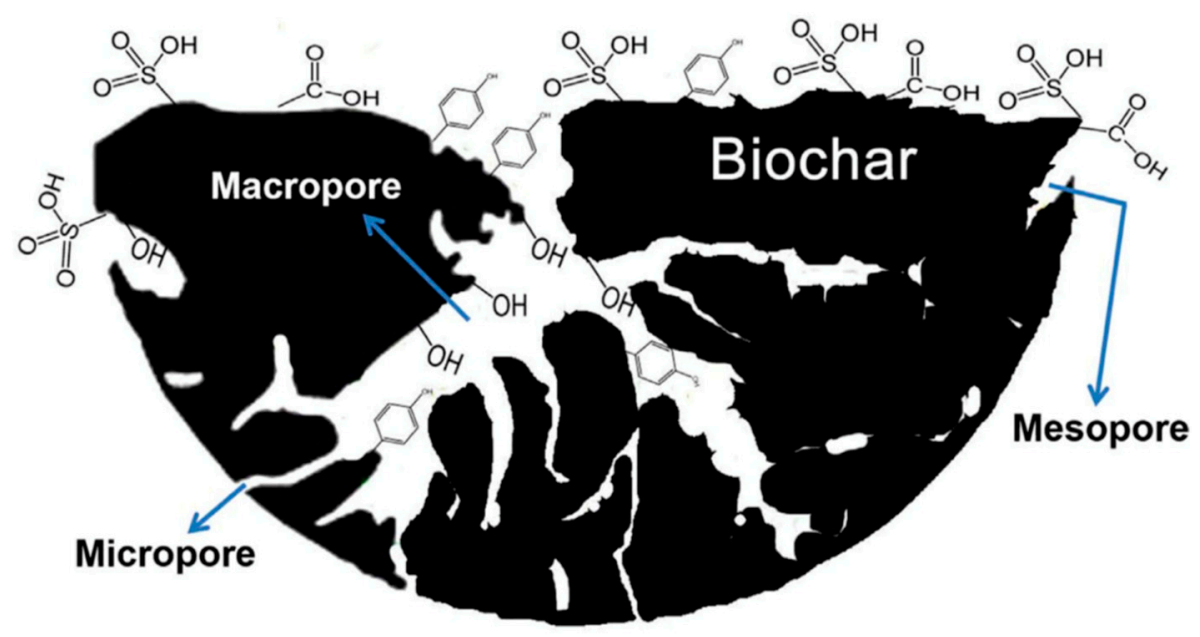

Figure 2. Morphology and the presence of functional groups in biochar. Reproduced with permission from [24]; Elsevier and Copyright Clearance Center, 2017.

\subsection{Graphene, Graphene Oxide, and Carbon Nanotubes (CNTs) for $\mathrm{CO}_{2}$ Capture}

CBMs can be dimension-less and less than $100 \mathrm{~nm}$ but in many forms. Nanomaterials are extensively used for different applications, owing to their downsized unique properties. They can be used as catalysts supports, adsorption, energy conversion, charge storage device preparation, filtration, electrode materials, conductive materials, and so many [49]. Graphene-based nanomaterials are also used for $\mathrm{CO}_{2}$ capture [49]. The development of new adsorbents with high capacity and high selectivity for reducing energy-related $\mathrm{CO}_{2}$ emissions is a topic of utmost global importance because of its implications in climate change mitigation. Recent advances in materials science and engineering suggest that graphene-based adsorbents are wonder material with many attractive properties and can deliver viable solutions to the challenges of developing cost-effective, energy-efficient, and high-volume adsorption-based $\mathrm{CO}_{2}$ capture technologies. To date, a wide range of graphene materials has been investigated to curb $\mathrm{CO}_{2}$ emissions from static sources of fossil fuel combustion. Table 2 represents the $\mathrm{CO}_{2}$ adsorption performance by graphene, graphene oxide, CNTs, and composite materials. Graphene-based materials, such as graphene oxide, have different oxygen-containing functional groups, which can show higher chemical reactivity over pristine graphene [50]. The introduction of different heteroatoms (e.g., N, boron B, aluminum Al, sulfur S, and so on) in graphene can increase the adsorption capacity of $\mathrm{CO}_{2}$. For example, Liu et al. [51] prepared $\mathrm{N}$ and B-doped graphene aerogels, which showed $\mathrm{CO}_{2}$ capture capacities of $2.9 \mathrm{mmol} / \mathrm{g}$ at $273 \mathrm{~K}$ and $1.0 \mathrm{bar}$ pressure. On the other hand, Bhanja et al. [52] did a modification of graphene oxide with 2,6-diformyl-4-methyl phenol. They reported that this material could capture $\mathrm{CO}_{2}$ up to $8.10 \mathrm{mmol} / \mathrm{g}$ at $273 \mathrm{~K}$. Recently, graphene-based monoliths have been prepared following a one-step water-based method, which has shown an excellent $\mathrm{CO}_{2}$ capture performance of $2.1 \mathrm{mmol} / \mathrm{g}$ at $298 \mathrm{~K}$ and 1 bar [53]. On the other hand, Huang et al. [54] synthesized a hybrid composite based on polyethyleneimine (PEI)-modified graphene oxide and ZIF-8. This composite showed a higher $\mathrm{CO}_{2}$ capture capacity of $8.08 \mathrm{mmol} / \mathrm{g}$ at $273 \mathrm{~K}$ and 1 bar. Rahimi et al. synthesized bundles of double-walled CNTs with an inner diameter of $8 \mathrm{~nm}$, and they reported excellent $\mathrm{CO}_{2}$ adsorption capacity (i.e., $3.5 \mathrm{mmol} / \mathrm{g}$ at $308 \mathrm{~K}$ and $1 \mathrm{bar}$ ) [55]. An improved innovative hydrate-based $\mathrm{CO}_{2}$ capture was observed by the rational surface modification of CNTs by Zhao et al. [56]. However, the maximum $\mathrm{CO}_{2}$ capture performance (up to $8.75 \mathrm{mmol} / \mathrm{g}$ at $196 \mathrm{~K}$ and 
1 bar) was observed by Jonathan et al. [57] by synthesizing a new composite based on single-walled carbon nanotube (SWCNT@HKUST-1).

Table 2. $\mathrm{CO}_{2}$ capture performances, recently reported by graphene, graphene oxide, carbon nanotubes (CNTs), and their composites.

\begin{tabular}{|c|c|c|c|c|c|}
\hline Adsorbent & $\begin{array}{l}\text { BET Surface } \\
\text { Area }\left(\mathrm{m}^{2} / \mathrm{g}\right)\end{array}$ & $\begin{array}{l}\text { Pressure } \\
\text { (Bar) }\end{array}$ & $\begin{array}{c}\text { Adsorption } \\
\text { Capacity }(\mathrm{mmol} / \mathrm{g}) \\
\text { at } 273 \mathrm{~K}\end{array}$ & $\begin{array}{c}\text { Adsorption } \\
\text { Capacity }(\mathrm{mmol} / \mathrm{g}) \\
\text { at } 298 \mathrm{~K}\end{array}$ & Reference \\
\hline Reduced graphene oxide & 1300 & 1 & 3.35 & 2.45 & [49] \\
\hline BN-graphene & 170 & 1 & 2.9 & 2.6 & [51] \\
\hline $\begin{array}{l}\text { Imine-functionalized graphene } \\
\text { oxide }\end{array}$ & 190 & 2 & 8.1 & 2.1 & [52] \\
\hline N-functionalized graphene & 979 & 1 & 5.8 & 2.7 & [58] \\
\hline $\begin{array}{l}\text { Polyetheleneimine (PEI)-modified } \\
\text { graphene oxide }\end{array}$ & 29 & 1 & - & 2.0 & [59] \\
\hline Graphene-based monolith & 328 & 1 & - & 2.1 & [53] \\
\hline PEI-graphene oxide@ZIF-8 & 190 & 1 & 8.08 & - & [54] \\
\hline DWCNTs & 423 & 1 & - & 3.5 (at $308 \mathrm{~K}$ ) & [55] \\
\hline PEI-purine-CNTs & & 1 & - & 3.9 (at $323 \mathrm{~K}$ ) & [60] \\
\hline PEI-CNT aerogels & 62 & 1 & - & 3.3 (at $343 \mathrm{~K}$ ) & [61] \\
\hline SWCNT@HKUST-1 & 1714 & 1 & - & 8.75 (at $196 \mathrm{~K}$ ) & [57] \\
\hline $\begin{array}{l}\text { Chitosan-polybenzoxazine } \\
\text { nanocomposite aerogels }\end{array}$ & 710 & 1 & 6.70 & 5.72 & [62] \\
\hline
\end{tabular}

On the other hand, Alhwaige et al. [63] synthesized chitosan aerogels with graphene oxide nanosheets, which showed $\mathrm{CO}_{2}$ capture capability up to $4.14 \mathrm{mmol} / \mathrm{g}$. Few other aerogels and cross-linked composites have been also reported, which have shown $\mathrm{CO}_{2}$ adsorption capacity up to $5.72 \mathrm{mmol} / \mathrm{g}$ at $298 \mathrm{~K}$ and $1 \mathrm{bar}$ [62].

Therefore, based on the above description, it can be clearly said that graphene, graphene oxide, and CNTs have $\mathrm{CO}_{2}$ capture ability, specifically in terms of high storage, excellent selectivity, rapid uptake, easy regeneration, and good reproducibility and stability. However, the maximum adsorption capacity comes from polyethyleneimine-modified graphene and graphene oxide compared to other graphene, graphene oxides, and CNTs. In comparison to other competing adsorbents, a key advantage of these material systems is that many different functional groups or heteroatoms can be attached to their surface, allowing custom-tailoring of surface properties without sacrificing the remarkable intrinsic characteristics of the graphene core. However, a number of technological limitations and practical challenges have to be tackled in order to produce next- generation graphene-based adsorbents with the capability of being applied on an industrial scale for efficient and effective $\mathrm{CO}_{2}$ separation from flue gases. Henceforth, future applications of such kinds of materials for $\mathrm{CO}_{2}$ capture need further consideration with mainly focusing on the significant improvement in the adsorption capacity as well as the low-cost production of these materials.

\subsection{Activated Carbons (ACs) for $\mathrm{CO}_{2}$ Capture}

Activated carbon is a high-porosity material, which is useful in adsorption and separation of many gas mixtures [64,65]. Perhaps, ACs have widely been used for $\mathrm{CO}_{2}$ capture compared to other types of CBMs. This is because they have high surface area (SA), pore-volume, and submicroscopic pores $[5,66,67]$. ACs are not degraded in acidic and basic conditions [68]. Hence, they possess excellent performance in $\mathrm{CO}_{2}$ uptake. Table 3 summarizes the $\mathrm{CO}_{2}$ capture performances by different ACs. 
Table 3. $\mathrm{CO}_{2}$ capture performances by different activated carbons (ACs).

\begin{tabular}{|c|c|c|c|c|c|}
\hline Adsorbent & $\begin{array}{l}\text { BET Surface } \\
\text { Area }\left(\mathrm{m}^{2} / \mathrm{g}\right)\end{array}$ & $\begin{array}{l}\text { Pressure } \\
\text { (Bar) }\end{array}$ & $\begin{array}{c}\text { Adsorption } \\
\text { Capacity }(\mathrm{mmol} / \mathrm{g}) \\
\text { at } 273 \mathrm{~K}\end{array}$ & $\begin{array}{c}\text { Adsorption } \\
\text { Capacity }(\mathrm{mmol} / \mathrm{g}) \\
\text { at } 298 \mathrm{~K}\end{array}$ & Reference \\
\hline AC beds & 3537 & 18 & - & 20.66 & [69] \\
\hline N-doped ACs & 1535 & 1 & 7.0 & 4.80 & [70] \\
\hline Starch-based ACs & 3350 & 1 & 4.4 & 3.4 & [71] \\
\hline Polyurethane foam-based AC & 1360 & 1 & 5.85 & - & [67] \\
\hline Polyacrylonitrile-based AC fibers & 1565 & 1 & - & 2.74 & {$[72]$} \\
\hline $\mathrm{N}$ and S-doped ACs & 2040 & 1 & 7.76 & 5.19 & [73] \\
\hline Celtuce leaves-derived AC & 3404 & 1 & 6.04 & 4.36 & [74] \\
\hline Longan shells-derived AC & 3260 & 1 & 5.60 & 4.30 & [75] \\
\hline Slash pine-derived AC & 906 & 1 & 4.93 & 3.86 (at $288 \mathrm{~K})$ & [76] \\
\hline Coconut shell-derived AC & 1327 & 1 & 5.60 & 3.90 & [77] \\
\hline Black locust-derived AC & 2511 & 1 & 5.86 & 3.75 & [44] \\
\hline Starch and cellulose, sawdust & 1260 & 1 & 6.10 & 4.8 & [28] \\
\hline Empty fruit bunch-derived AC & 1720 & 1 & 5.22 & 3.70 & [78] \\
\hline Lignin-derived AC & 3500 & 1 & 8.20 & 4.8 & [79] \\
\hline Pitch-based N-doped AC & 1505 & 1 & 7.10 & 4.58 & [80] \\
\hline
\end{tabular}

ACs can be derived from biomass through pyrolysis but requires either physical or chemical activation. Physical activation can be performed using steam/water vapor, air, or $\mathrm{CO}_{2}$. On the other hand, carbon can also be chemically activated by various chemicals to increase the surface area, as well as add (or remove) specific surface functional groups. When carbon is activated with ammonia at high temperatures, nitrogenous groups are added, and acidic oxygen groups are removed, which significantly improves basicity (Shafeeyan et al., 2020) [81].

However, different precursors, such as biomasses, coal, and petroleum pitch, are used for the production of ACs. However, mostly used precursors are biomasses, coal, and petroleum pitch [82]. For example, Shao et al. [71] synthesized ACs from coal tar pitch with an extremely high surface area of $3537 \mathrm{~m}^{2} / \mathrm{g}$. This AC could capture $\mathrm{CO}_{2}$ up to $20.66 \mathrm{mmol} / \mathrm{g}$ at $298 \mathrm{~K}$ and 18 bar. On the other hand, ACs can also be prepared from different biomass precursors. For instance, Chen et al. [67] synthesized $\mathrm{N}$-doped microporous-ACs from coconut shells by using urea as an activating agent. They found the $\mathrm{CO}_{2}$ capture capacity of 7.0 and $4.8 \mathrm{mmol} / \mathrm{g}$ at 273 and $298 \mathrm{~K}$, respectively, at 1 bar. An ultrahigh-surface area of ACs $\left(3350 \mathrm{~m}^{2} / \mathrm{g}\right)$ was achieved by using starch as a source of a precursor. These ACs could capture $\mathrm{CO}_{2}$ up to $3.4 \mathrm{mmol} / \mathrm{g}$ at $298 \mathrm{~K}$ and 1 bar [72]. On the other hand, polyurethane foam-based AC was synthesized by Ge et al. [67], whose adsorption capacity was $5.85 \mathrm{mmol} / \mathrm{g}$ at $273 \mathrm{~K}$ and $1 \mathrm{bar}$. In another study, the $\mathrm{CO}_{2}$ removal capacity of polyacrylonitrile-based AC fibers at $298 \mathrm{~K}$ and 1 bar was reported to be $2.74 \mathrm{mmol} / \mathrm{g}$ [72]. It is reported that each year, around 140 billion metric tons of biomasses are produced from agriculture resources [73]. So, the proper utilization of agricultural wastes together with other biomass sources, such as food residues, nutshells, cellulose craft, lignin, sawdust, rice husk, chips, logs, wood processing residues, marine microalgae, and pitch, for the production of ACs in an environmentally friendly, as well as an economic way, could be an alternative solution. Such an example is given in Figure 3, where celtuce leaves were pyrolyzed at a high temperature, followed by a chemical activation process [74].

In summary, it can be mentioned that ACs materials are excellent materials for the adsorption of $\mathrm{CO}_{2}$ with higher adsorption capacity, as well as they can be prepared from low-cost materials. ACs have higher potential for commercial applications as they have higher adsorption capacity, high surface area, microporosity, mesoporosity, and stability. Hence, AC is one of the top performance CBMs for the $\mathrm{CO}_{2}$ capture. 
(a)
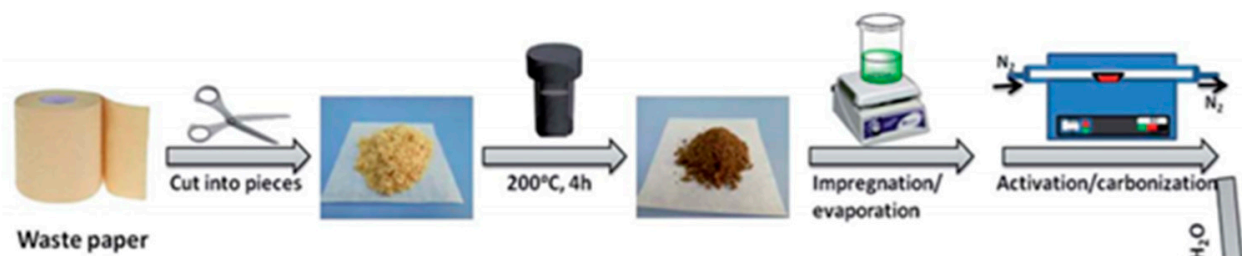

Waste paper evaporation

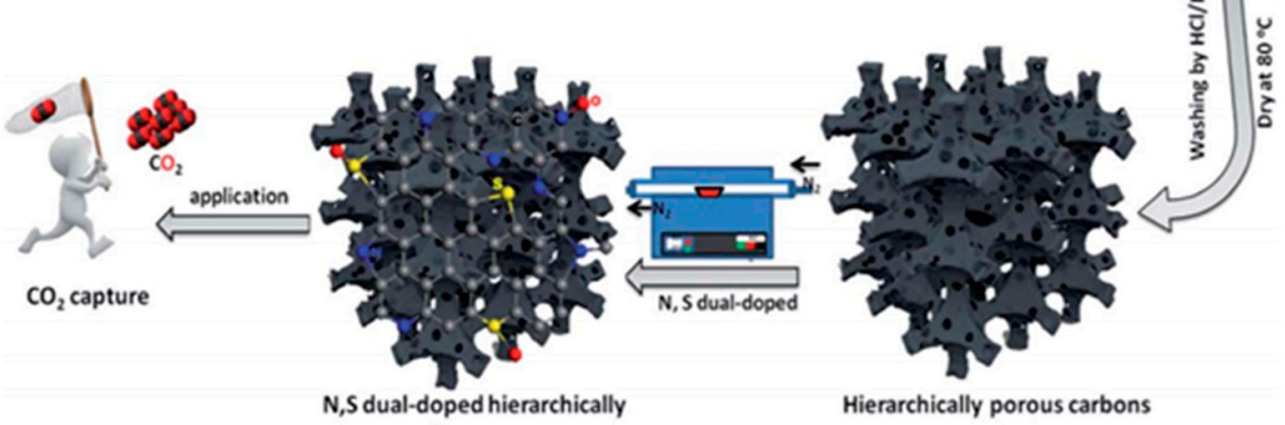
porous carbons

Hierarchically porous carbons

(b)

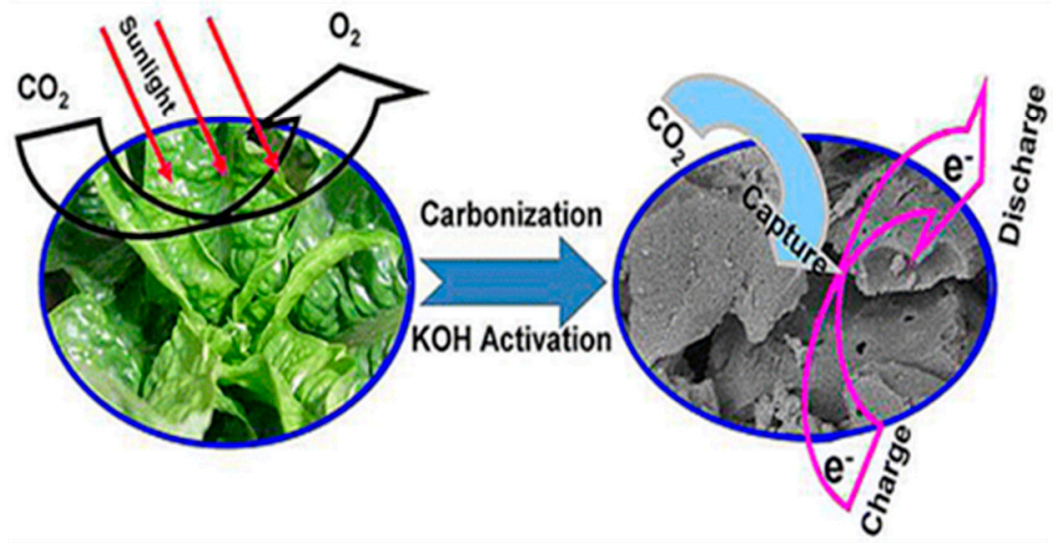

Figure 3. ACs (activated carbons) preparation from (a) waste paper and (b) biomass [73,74]. Reproduced with permissions from the references of [73,74]; Copyright (C) 2019, Royal Society of Chemistry and Copyright (C) 2012, American Chemical Society; respectively.

\subsection{Microporous, Mesoporous, and Hierarchical Porous Carbons for $\mathrm{CO}_{2}$ Capture}

Porous carbon materials have versatile properties, such as high Brunauer-Emmett-Teller (BET) surface area, adjustable pore structure, cost-effective, and easy regeneration [83]. Generally, there are three different types of porous carbon materials, i.e., microporous $(<2 \mathrm{~nm})$, mesoporous $(2-50 \mathrm{~nm})$, and macroporous (>50 nm), but hierarchical porous carbon (HPC) consists all of these properties [84]. For example, Lizen et al. [85] synthesized super porous carbon materials with $95 \%$ mesoporosity using polypyrrole as a precursor material. They mentioned about the ultra-high surface area (i.e., $2800-4000 \mathrm{~m}^{2} / \mathrm{g}$ ) and pore volume (i.e., $2.5-3.6 \mathrm{~cm}^{3} / \mathrm{g}$ ). However, their $\mathrm{CO}_{2}$ capture capacity was found to be $2.8 \mathrm{mmol} / \mathrm{g}$ at $298 \mathrm{~K}$. On the other hand, it was found that the mesoporosity was significantly increased by using sodium amide $\left(\mathrm{NaNH}_{2}\right)$ during activation and doping with magnesium $(\mathrm{Mg})$ and nitrogen $\left(\mathrm{N}_{2}\right)$. These materials showed excellent $\mathrm{CO}_{2}$ uptake performance $(3.68-6.31 \mathrm{mmol} / \mathrm{g}$ at 273 K) [86-88]. On the other hand, Park et al. [89] synthesized 3D ordered mesoporous carbon and observed the $\mathrm{CO}_{2}$ capture capacity of $5.53 \mathrm{mmol} / \mathrm{g}$. Recently, a newly designed porous geopolymer template was developed by Pei et al. [90], which was based on the metakaolin. This AC had an excellent $\mathrm{CO}_{2}$ capture performance of $26.30 \mathrm{mmol} / \mathrm{g}$ at $273 \mathrm{~K}$ and $30 \mathrm{bar}$ (Table 4). HPC ordered materials have great potential for high $\mathrm{CO}_{2}$ capture as they have great interest due to their many advantages, such as high microporosity, high surface area, higher microporous quantity, and so on. For example, HPC with a prominent BET surface area up to $2734 \mathrm{~m}^{2} / \mathrm{g}$ had higher $\mathrm{CO}_{2}$ capture performance up to $27 \mathrm{mmol} / \mathrm{g}$ at 
30 bar and $300 \mathrm{~K}$ [91]. Hence, carbon nanomaterials can possess a hierarchical porous structure and contain both macropores and micropores structure. These properties of carbon, together with the high surface area, are very important for higher $\mathrm{CO}_{2}$ capture [92].

Table 4. $\mathrm{CO}_{2}$ capture performances by microporous, mesoporous, and hierarchical porous carbons.

\begin{tabular}{|c|c|c|c|c|c|}
\hline Adsorbent & $\begin{array}{l}\text { BET Surface } \\
\text { Area }\left(\mathrm{m}^{2} / \mathrm{g}\right)\end{array}$ & $\begin{array}{l}\text { Pressure } \\
\text { (bar) }\end{array}$ & $\begin{array}{c}\text { Adsorption } \\
\text { Capacity (mmol/g) } \\
\text { at } 273 \mathrm{~K}\end{array}$ & $\begin{array}{c}\text { Adsorption } \\
\text { Capacity }(\mathrm{mmol} / \mathrm{g}) \\
\text { at } 298 \mathrm{~K}\end{array}$ & Reference \\
\hline Mesoporous carbon & 3934 & 1 & - & 2.8 & [85] \\
\hline $\begin{array}{l}\mathrm{NaNH}_{2} \text {-activated mesoporous } \\
\text { carbon }\end{array}$ & 3325 & 1 & 6.31 & 3.66 & [86] \\
\hline $\begin{array}{l}\mathrm{Mg} \text { and } \mathrm{N} \text {-doped mesoporous } \\
\text { carbon }\end{array}$ & 541 & 1 & 3.68 & - & [87] \\
\hline $\mathrm{N}$-doped mesoporous carbon & 984.91 & & & 4.23 (at $303 \mathrm{~K}$ ) & [88] \\
\hline $\begin{array}{c}\text { Ordered mesoporous carbon } \\
\text { nitrides }\end{array}$ & 232 & 30 & 5.63 & & [89] \\
\hline Ordered mesoporous carbon & 2255 & 1 & 3.0 & 2.1 & [93] \\
\hline Ultramicroporous carbon & 882 & 1 & 5.91 & 4.30 & [94] \\
\hline Mesoporous carbon nanospheres & 1240 & 1 & 4.76 & 2.36 & [95] \\
\hline Microporous carbon & 1551 & 30 & 26.30 & - & [90] \\
\hline $\mathrm{N}$-doped microporous carbon & 664 & 1 & 5.0 & 4.0 & [96] \\
\hline Ultramicroporous carbon & 1059 & 1 & 5.87 & 3.82 & [97] \\
\hline Microporous carbon aerogel & 1871 & 1 & - & 3.0 & [98] \\
\hline $\mathrm{N}$-doped microporous carbon & 1060 & 1 & - & 4.24 & [99] \\
\hline Microporous carbon beads & 1755 & & 6.15 & 4.25 & [100] \\
\hline $\mathrm{N}$-doped microporous carbon & 1381 & 1 & 5.91 & 3.86 & [101] \\
\hline Ultra microporous carbon & 335 & 1 & - & 1.82 (at $303 \mathrm{~K}$ ) & [102] \\
\hline S-doped microporous carbon & 1567 & 1 & - & 4.5 & [103] \\
\hline N-doped porous carbon & 467 & 1 & - & 3.13 & [104] \\
\hline $\begin{array}{l}\text { Ultra microporous carbon } \\
\text { nanoplates }\end{array}$ & 800 & 1 & - & 5.2 & [105] \\
\hline Yeast-based porous carbon & 1348 & 1 & - & 5.0 & [106] \\
\hline Sponge-like porous carbon & 1143 & 1 & 5.6 & 4.0 & [107] \\
\hline Hierarchical porous carbon & 2734 & 30 & - & 27.0 (at $300 \mathrm{~K}$ ) & [91] \\
\hline Hierarchical porous carbon nitride & 550 & 1 & - & 2.9 & [108] \\
\hline Hierarchical porous carbon & 2698 & 1 & - & 3.7 & [109] \\
\hline Hierarchical nanosheet & 1555.7 & 1 & 4.62 & 3.10 & [110] \\
\hline $\begin{array}{l}\text { N-doped hierarchical porous } \\
\text { carbon }\end{array}$ & 1455.1 & 1 & 6.22 & 4.05 & [111] \\
\hline $\begin{array}{l}\text { Waste wool-derived N-doped } \\
\text { hierarchical porous carbon }\end{array}$ & 1352 & 1 & 3.72 & 2.78 & [112] \\
\hline $\begin{array}{l}\text { N-doped hierarchical porous } \\
\text { carbon }\end{array}$ & 2799 & 1 & 5.3 & 4.4 & [113] \\
\hline Si-doped porous carbon & 1500 & 1 & 7.8 & 4.0 (at $296 \mathrm{~K}$ ) & [114] \\
\hline
\end{tabular}

Porous carbon materials have drawn great attention due to the remarkable pore structure, high specific surface area, large pore volume, excellent property of adsorption, and separation. When the material is highly microporous, it may result in a long equilibrium time for $\mathrm{CO}_{2}$ adsorption. Large mesopores enable faster transfer of gas from the bulk phase to micropores and, thus, result in faster equilibrium $[113,114]$. Although microporous and mesoporous content has been found to be the best indicator of $\mathrm{CO}_{2}$ capture performance, a large pore volume values originating from a distinct large mesoporous peak can improve $\mathrm{CO}_{2}$ performance as well. So, utilizing the hierarchical porous carbon materials by adjusting various templates and catalysis with large pore volume and high surface area would be the best candidate for reducing the emission of $\mathrm{CO}_{2}$ to the environment.

\section{Comparative Analysis of CBMs Performances}

CBMs are found to be very effective in the capture of $\mathrm{CO}_{2}$ at various conditions with varying degree of adsorption capacity. We know that different adsorbents have been produced at different conditions using different precursors. Based on rough estimation, it can be mentioned that biochar and activated biochar are cheap materials compared to any other CBMS. Table 5 lists the rough lower and higher prices of each CBMs, although the actual cost may vary depending on several factors, such as purity, quality, quantity, and so on. Based on the table, it can be seen that carbon-based 
nanomaterials, such as graphene, graphene oxide, and CNTs, have a higher cost compared to other types of CBMs. Besides, the further modification of those materials can significantly increase the cost, such as composite materials preparation and fabrication for the end-use. However, their average $\mathrm{CO}_{2}$ adsorption capacity values were $5.13 \pm 1.62$ and $3.23 \pm 1.13 \mathrm{mmol} / \mathrm{g}$, respectively, at 273 and $298 \mathrm{~K}$, which was even lower than that of cheap materials, such as biochar at both temperatures (Figure 4). These results indicate that graphene, graphene oxide, and $\mathrm{CNT}$ s have lower $\mathrm{CO}_{2}$ adsorption capacity compared to biochar and activated biochar and even compared with other types of CBMs.

Table 5. Rough prices of different carbon-based adsorbents [115]. Price varies based on purity, quantity, quality, and type of materials.

\begin{tabular}{ccc}
\hline Adsorbents & Lower Price $\mathbf{( \$ \mathbf { k g } )}$ & Higher Price $\mathbf{( \$ / \mathbf { k g } )}$ \\
\hline Biochar/activated biochar & 0.4 & 0.90 \\
Activated carbons & 2.90 & 8.20 \\
CNTs & 1000 & 10,000 \\
Graphene & 50 & 200 \\
Graphene oxide & 200 & 400 \\
Other carbons & Depends on processing & Depends on processing \\
\hline
\end{tabular}
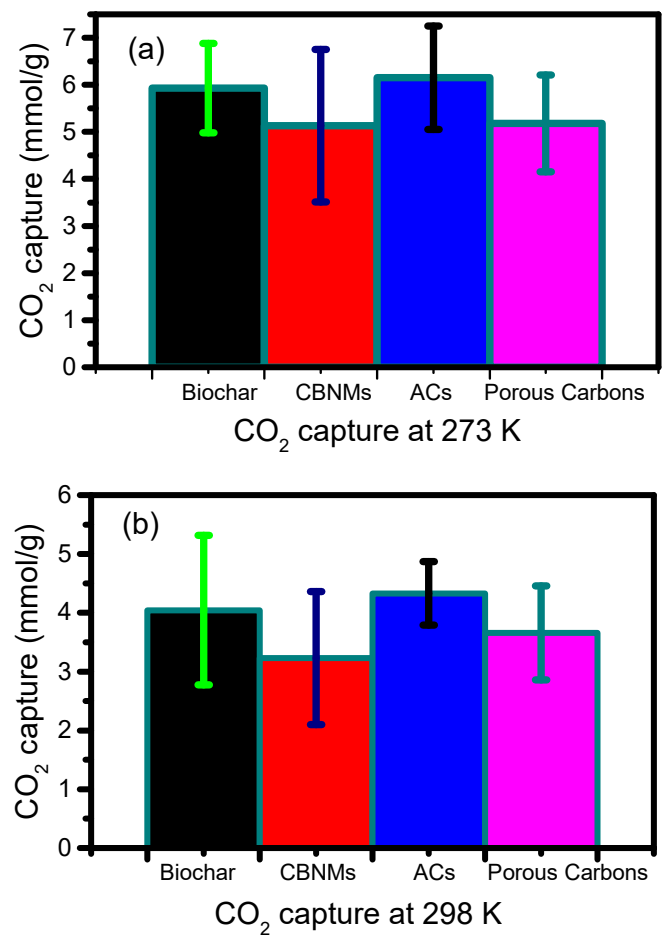

Figure 4. Average (with standard deviation) $\mathrm{CO}_{2}$ capture performance by different carbon-based materials at two different temperatures, i.e., $273 \mathrm{~K}$ and $298 \mathrm{~K}$, respectively. Biochar refers to biochar and activated biochar; CBNMs refers to graphene, graphene oxide, CNTs, and their composites; porous carbon refers to micro, meso, and hierarchical porous carbons. Each set of data refers to the average value (with standard deviation) at the adsorption capacities of each type of material, which was generated from Tables 1-4.

On the other hand, biochar and activated biochar have higher $\mathrm{CO}_{2}$ capture performance over graphene, graphene oxides, and CNTs, although some special cases can cease this estimation. On the right side, different meso-micro and hierarchical porous carbons have slightly lower $\mathrm{CO}_{2}$ adsorption capacities than that of biochar, and they have higher efficacy over graphene, graphene oxides, and CNTs. Hence, biochar and activated biochar have a higher potential for the capture of $\mathrm{CO}_{2}$ than hierarchical porous carbons. 
However, ACs have been found very effective among all types of CBMs with the higher average $\mathrm{CO}_{2}$ capture performances $(6.15 \pm 1.10,4.33 \pm 0.54 \mathrm{mmol} / \mathrm{g}$, respectively, at 273 and $298 \mathrm{~K})$ at both temperatures (Figure 4). These average values indicate that $\mathrm{ACs}$ have higher $\mathrm{CO}_{2}$ capacities over biochar, activated biochar, hierarchical porous carbons, graphene, graphene oxide, and CNTs. These are mainly due to their high surface area and the properties of ultra-microporous structures. Therefore, ACs are the top performance materials for the capture of $\mathrm{CO}_{2}$. However, there might have some other form of carbons that can overcome these estimations, but grossly ACs are the highly efficient materials for $\mathrm{CO}_{2}$ capture. Hence, for $\mathrm{CO}_{2}$ capture, $\mathrm{CBMs}$ follow the order of carbon nanomaterials (i.e., graphene, graphene oxides, $\mathrm{CNTs}$, and their composites) $<$ meso-micro or hierarchical porous carbons $<$ biochar and activated biochar $<$ activated carbons.

\section{Future Challenges and Opportunities}

Although enough progress has been done towards the synthesis of CBMs and application for $\mathrm{CO}_{2}$ capture, still there is a lack of studies. For example, it is highly necessary to consider the effects of different parameters, such as the presence of moisture, foreign ions, environmental conditions, neutral and ionic species, and so many, for the effective capture of $\mathrm{CO}_{2}$ and to measure the overall efficacy of CBMs from the atmosphere [116]. Therefore, further investigations are needed in many areas. They are:

i. Developments of the novel composite to improve the capture performance of $\mathrm{CO}_{2}$ of $\mathrm{CBMs}$.

ii. A need to properly understate the $\mathrm{CO}_{2}$ interactions with $\mathrm{CBMs}$. For this reason, new analytical tools are needed to develop.

iii. Ensuring the regeneration efficiency for repeatable applications. Regeneration mechanisms also need to study in detail.

iv. Development of new technologies for the efficient capture of $\mathrm{CO}_{2}$.

v. A highly efficient carbon-based catalyst needs to develop for the conversion of $\mathrm{CO}_{2}$ into valuable fuels, such as methane.

vi. Low-cost materials with high adsorption capacity need to develop.

vii. Most of the CBMs have been used for $\mathrm{CO}_{2}$ capture on a lab-scale basis, i.e., from ambient air. However, studies are not enough. Therefore, more studies are required.

viii. Other types of materials, such as metal-organic frameworks, porous silica, resin, amine derivatives sorbents, and new types of materials, need to produce with lower cost for the scale-up process.

ix. These coatings of sorbents can help for faster heat and mass transfer, as well as can reduce energy losses. Therefore, these kinds of sorbents need to develop.

x. Detailed kinetics of sorption and mechanisms need to be focused on more clearly.

xi. Combining together and application of the different existing technologies can reduce the cost of the capture of $\mathrm{CO}_{2}$.

\section{Conclusions}

CBMs are very efficient in the capture of $\mathrm{CO}_{2}$ from the air at different temperatures and pressures due to their specific properties, including high surface area, mesoporosity, microporosity, micropore volume, well-defined pore size distributions, and high stability, at different environmental conditions. Among different $\mathrm{CBMs}$, activated carbons and activated biochar are found to be the top performance materials for the capture of $\mathrm{CO}_{2}$ in an environmentally friendly way. Although extensive research has been carried out for the development of different suitable carbon-based materials for $\mathrm{CO}_{2}$ capture, still there is a lack of research for future studies on the development of low-cost suitable adsorbent material. In our opinion, $\mathrm{CBMs}$ have a good future for $\mathrm{CO}_{2}$ capture if all the properties can be merged into one material, which can compete with metal-organic frameworks. Therefore, the future focus should be given on the increase in the adsorption capacity, as well as materials properties, in order to sustain in the long future. 
Author Contributions: T.K., M.S.H., M.A.H. and M.B.A. have collected data, designed the manuscript and written the main text. P.K.D., and M.S.R., have collected data and revised the manuscript. M.B.A., and M.A.H., have monitored, revised, designed and written the manuscript. All authors have read and agreed to the published version of the manuscript.

Funding: This research received no external funding.

Conflicts of Interest: The authors declare no conflict of interest.

\section{References}

1. Siriwardane, R.V.; Shen, M.; Fisher, E.P.; Poston, J.A. Adsorption of $\mathrm{CO}_{2}$ on molecular sieves and activated carbon. Energy Fuels 2001, 15, 279-284. [CrossRef]

2. Lopes, F.V.S.; Grande, C.A.; Ribeiro, A.M.; Loureiro, J.M.; Evaggelos, O.; Nikolakis, V.; Rodrigues, A.E. Adsorption of $\mathrm{H}_{2}, \mathrm{CO}_{2}, \mathrm{CH}_{4}, \mathrm{CO}, \mathrm{N}_{2}$ and $\mathrm{H}_{2} \mathrm{O}$ in activated carbon and zeolite for hydrogen production. Sep. Sci. Technol. 2009, 44, 1045-1073. [CrossRef]

3. Haque, E.; Islam, M.M.; Pourazadi, E.; Sarkar, S.; Harris, A.T.; Minett, A.I.; Yanmaz, E.; Alshehri, S.M.; Ide, Y.; $\mathrm{Wu}, \mathrm{K} . \mathrm{C} . \mathrm{W}$. Boron-functionalized graphene oxide-organic frameworks for highly efficient $\mathrm{CO}_{2}$ capture. Chem. Asian. J. 2017, 12, 283-288. [CrossRef] [PubMed]

4. Creamer, A.E.; Gao, B. Carbon-based adsorbents for postcombustion $\mathrm{CO}_{2}$ capture: A critical review. Environ. Sci. Technol. 2016, 50, 7276-7289. [CrossRef]

5. Alam, M.M.; Hossain, M.A.; Hossain, M.D.; Johir, M.; Hossen, J.; Rahman, M.S.; Zhou, J.L.; Hasan, A.; Karmakar, A.K.; Ahmed, M.B. The potentiality of rice husk-derived activated carbon: From synthesis to application. Processes 2020, 8, 203. [CrossRef]

6. Rubin, E.; De Coninck, H. IPCC special report on carbon dioxide capture and storage. In TNO (2004): Cost Curves for CO2 Storage, Part 2; Cambridge University Press: Cambridge, UK, 2005; Volume 2, p. 14.

7. Li, J.R.; Ma, Y.; McCarthy, M.C.; Sculley, J.; Yu, J.; Jeong, H.K.; Balbuena, P.B.; Zhou, H.C. Carbon dioxide capture-related gas adsorption and separation in metal-organic frameworks. Coord. Chem. Rev. 2011, 255, 1791-1823. [CrossRef]

8. D'Alessandro, D.M.; Smit, B.; Long, J.R. Carbon dioxide capture: Prospects for new materials. Angez. Chem. Int. Ed. 2010, 49, 6058-6082. [CrossRef]

9. Shi, X.; Xiao, H.; Lackner, K.S.; Chen, X. Capture $\mathrm{CO}_{2}$ from ambient air using nanoconfined ion hydration. Angew. Chem. 2016, 128, 4094-4097. [CrossRef]

10. Shi, X.; Xiao, H.; Azarabadi, H.; Song, J.; Wu, X.; Chen, X.; Lackner, K.S. Sorbents for direct capture of $\mathrm{CO}_{2}$ from ambient air. Angew. Chem. Int. Ed. 2020, 99, 6984-7006. [CrossRef]

11. Ren, X.; Li, H.; Chen, J.; Wei, L.; Modak, A.; Yang, H.; Yang, Q. N-doped porous carbons with exceptionally high $\mathrm{CO}_{2}$ selectivity for $\mathrm{CO}_{2}$ capture. Carbon 2017, 114, 473-481. [CrossRef]

12. Hao, G.P.; Jin, Z.Y.; Sun, Q.; Zhang, X.Q.; Zhang, J.T.; Lu, A.H. Porous carbon nanosheets with precisely tunable thickness and selective $\mathrm{CO}_{2}$ adsorption properties. Energy Environ. Sci. 2013, 6, 3740-3747. [CrossRef]

13. Zhang, L.H.; Li, W.C.; Tang, L.; Wang, Q.G.; Hu, Q.T.; Zhang, Y.; Lu, A.H. Primary amine modulated synthesis of two-dimensional porous nanocarbons with tunable ultramicropores. J. Mater. Chem. A 2018, 6, 24285-24290. [CrossRef]

14. Qian, D.; Lei, C.; Wang, E.M.; Li, W.C.; Lu, A.H. A method for creating microporous carbon materials with excellent $\mathrm{CO}_{2}$-adsorption capacity and selectivity. ChemSusChem 2014, 7, 291-298. [CrossRef] [PubMed]

15. Drage, T.C.; Kozynchenko, O.; Pevida, C.; Plaza, M.G.; Rubiera, F.; Pis, J.; Snape, C.E.; Tennison, S. Developing activated carbon adsorbents for pre-combustion $\mathrm{CO}_{2}$ capture. Energy Proced. 2009, 1, 599-605. [CrossRef]

16. Lu, C.; Bai, H.; Wu, B.; Su, F.; Hwang, J.F. Comparative study of CO2 capture by carbon nanotubes, activated carbons, and zeolites. Energy Fuels 2008, 22, 3050-3056. [CrossRef]

17. Yu, C.H.; Huang, C.H.; Tan, C.S. A review of $\mathrm{CO}_{2}$ capture by absorption and adsorption. Aerosol Air Qual. Res. 2012, 12, 745-769. [CrossRef]

18. Kim, I.; Svendsen, H.F. Heat of absorption of carbon dioxide $\left(\mathrm{CO}_{2}\right)$ in monoethanolamine (MEA) and 2-(aminoethyl) ethanolamine (AEEA) solutions. Ind. Eng. Chem. 2007, 46, 5803-5809. [CrossRef]

19. Choi, S.; Drese, J.H.; Jones, C.W. Adsorbent materials for carbon dioxide capture from large anthropogenic point sources. ChemSusChem: Chem. Sust. Energy Mater. 2009, 2, 796-854. [CrossRef] 
20. Qian, K.; Kumar, A.; Zhang, H.; Bellmer, D.; Huhnke, R. Recent advances in utilization of biochar. Renew. Sust. Energy Rev. 2015, 42, 1055-1064. [CrossRef]

21. Tan, X.F.; Liu, S.B.; Liu, Y.G.; Gu, Y.L.; Zeng, G.M.; Hu, X.J.; Wang, X.; Liu, S.H.; Jiang, L.H. Biochar as potential sustainable precursors for activated carbon production: Multiple applications in environmental protection and energy storage. Bioresour. Technol. 2017, 227, 359-372. [CrossRef]

22. Woolf, D.; Amonette, J.E.; Street-Perrott, F.A.; Lehmann, J.; Joseph, S. Sustainable biochar to mitigate global climate change. Nat. Commun. 2010, 1, 56. [CrossRef]

23. Ahmed, M.B.; Zhou, J.L.; Ngo, H.H.; Guo, W. Insight into biochar properties and its cost analysis. Biomass Bioenerg. 2016, 84, 76-86. [CrossRef]

24. Lee, J.; Kim, K.H.; Kwon, E.E. Biochar as a catalyst. Renew. Sustain. Energy Rev. 2017, 77, 70-79. [CrossRef]

25. You, S.; Ok, Y.S.; Chen, S.S.; Tsang, D.C.; Kwon, E.E.; Lee, J.; Wang, C.H. A critical review on sustainable biochar system through gasification: Energy and environmental applications. Bioresour. Technol. 2017, 246, 242-253. [CrossRef] [PubMed]

26. Lehmann, J.; Gaunt, J.; Rondon, M. Bio-char sequestration in terrestrial ecosystems-a review. Mitig. Adapt. Strat. Glob. Change 2006, 11, 403-427. [CrossRef]

27. Balahmar, N.; Mitchell, A.C.; Mokaya, R. Generalized Mechanochemical Synthesis of Biomass-derived sustainable carbons for high performance $\mathrm{CO}_{2}$ storage. Adv. Energy Mater. 2015, 5. [CrossRef]

28. Sevilla, M.; Fuertes, A.B. Sustainable porous carbons with a superior performance for $\mathrm{CO}_{2}$ capture. Energy Environ. Sci. 2011, 4, 1765-1771. [CrossRef]

29. Nanda, S.; Dalai, A.K.; Berruti, F.; Kozinski, J.A. Biochar as an exceptional bioresource for energy, agronomy, carbon sequestration, activated carbon and specialty materials. Waste Biomass Valori. 2016, 7, 201-235. [CrossRef]

30. Guizani, C.; Haddad, K.; Jeguirim, M.; Colin, B.; Limousy, L. Combustion characteristics and kinetics of torrefied olive pomace. Energy 2016, 107, 453-463. [CrossRef]

31. Rousset, P.; Macedo, L.; Commandre, J.M.; Moreira, A. Biomass torrefaction under different oxygen concentrations and its effect on the composition of the solid by-product. J. Anal. Appl. Pyrol. 2012, 96, 86-91. [CrossRef]

32. Ullah, H.; Liu, G.J.; Yousaf, B.; Ali, M.U.; Abbas, Q.; Zhou, C.C. Combustion characteristics and retention-emission of selenium during co-firing of torrefied biomass and its blends with high ash coal. Bioresour. Technol. 2017, 245, 73-80. [CrossRef] [PubMed]

33. Liu, W.J.; Jiang, H.; Yu, H.Q. Development of biochar-based functional materials: Toward a sustainable platform carbon material. Chem. Rev. 2015, 115, 12251-12285. [CrossRef] [PubMed]

34. Keiluweit, M.; Nico, P.S.; Johnson, M.G.; Kleber, M. Dynamic molecular structure of plant biomass-derived black carbon (biochar). Environ. Sci. Technol. 2010, 44, 1247-1253. [CrossRef] [PubMed]

35. Mohd, A.; Ghani, W.A.W.A.; Resitanim, N.Z.; Sanyang, L. A Review: Carbon dioxide capture: Biomass-derived-biochar and its applications. J. Disper. Sci. Technol. 2013, 34, 974-984. [CrossRef]

36. Manyà, J.J.; González, B.; Azuara, M.; Arner, G. Ultra-microporous adsorbents prepared from vine shoots-derived biochar with high $\mathrm{CO}_{2}$ uptake and $\mathrm{CO}_{2} / \mathrm{N}_{2}$ selectivity. Chem. Eng. 2018, 345, 631-639. [CrossRef]

37. Ello, A.S.; de Souza, L.K.; Trokourey, A.; Jaroniec, M. Development of microporous carbons for $\mathrm{CO}_{2}$ capture by $\mathrm{KOH}$ activation of African palm shells. J. CO2 Util. 2013, 2, 35-38. [CrossRef]

38. Li, D.W.; Ma, T.F.; Zhang, R.L.; Tian, Y.Y.; Qiao, Y.Y. Preparation of porous carbons with high low-pressure $\mathrm{CO}_{2}$ uptake by $\mathrm{KOH}$ activation of rice husk char. Fuel 2015, 139, 68-70. [CrossRef]

39. Deng, S.B.; Wei, H.R.; Chen, T.; Wang, B.; Huang, J.; Yu, G. Superior $\mathrm{CO}_{2}$ adsorption on pine nut shell-derived activated carbons and the effective micropores at different temperatures. Chem. Eng. 2014, 253, 46-54. [CrossRef]

40. Hong, S.M.; Jang, E.; Dysart, A.D.; Pol, V.G.; Lee, K.B. $\mathrm{CO}_{2}$ capture in the sustainable wheat-derived activated microporous carbon compartments. Sci. Rep. 2016, 6. [CrossRef]

41. Coromina, H.M.; Walsh, D.A.; Mokaya, R. Biomass-derived activated carbon with simultaneously enhanced $\mathrm{CO}_{2}$ uptake for both pre and post combustion capture applications. J. Mater. Chem. A 2016, 4, 280-289. [CrossRef] 
42. Serafin, J.; Narkiewicz, U.; Morawski, A.W.; Wrobel, R.J.; Michalkiewicz, B. Highly microporous activated carbons from biomass for $\mathrm{CO}_{2}$ capture and effective micropores at different conditions. J. CO2 Util. 2017, 18, 73-79. [CrossRef]

43. Zhang, C.M.; Song, W.; Ma, Q.L.; Xie, L.J.; Zhang, X.C.; Guo, H. Enhancement of $\mathrm{CO}_{2}$ capture on biomass-based carbon from black locust by $\mathrm{KOH}$ activation and ammonia modification. Energy Fuels 2016, 30, 4181-4190. [CrossRef]

44. Rouzitalab, Z.; Maklavany, D.M.; Rashidi, A.; Jafarinejad, S. Synthesis of N-doped nanoporous carbon from walnut shell for enhancing $\mathrm{CO}_{2}$ adsorption capacity and separation. J. Environ. Chem. Eng. 2018, 6, 6653-6663. [CrossRef]

45. Zhu, B.J.; Shang, C.X.; Guo, Z.X. Naturally nitrogen and calcium-doped nanoporous carbon from pine cone with superior $\mathrm{CO}_{2}$ capture capacities. ACS Sustain. Chem. Eng. 2016, 4, 1050-1057. [CrossRef]

46. Bamdad, H.; Hawboldt, K.; MacQuarrie, S. Nitrogen functionalized biochar as a renewable adsorbent for efficient $\mathrm{CO}_{2}$ removal. Energy Fuels 2018, 32, 11742-11748. [CrossRef]

47. Lahijani, P.; Mohammadi, M.; Mohamed, A.R. Metal incorporated biochar as a potential adsorbent for high capacity $\mathrm{CO}_{2}$ capture at ambient condition. J. CO2 Util. 2018, 26, 281-293. [CrossRef]

48. Dissanayake, P.D.; You, S.; Igalavithana, A.D.; Xia, Y.; Bhatnagar, A.; Gupta, S.; Kua, H.W.; Kim, S.; Kwon, J.H.; Tsang, D.C.W.; et al. Biochar-based adsorbents for carbon dioxide capture: A critical review. Renew. Sustain. Energy Rev. 2020, 119, 109582. [CrossRef]

49. Chowdhury, S.; Balasubramanian, R. Three-dimensional graphene-based porous adsorbents for postcombustion $\mathrm{CO}_{2}$ capture. Ind. Eng. Chem. 2016, 55, 7906-7916. [CrossRef]

50. Nasrollahzadeh, M.; Atarod, M.; Jaleh, B.; Gandomirouzbahani, M. In situ green synthesis of Ag nanoparticles on graphene oxide/ $\mathrm{TiO}_{2}$ nanocomposite and their catalytic activity for the reduction of 4-nitrophenol, congo red and methylene blue. Ceram. Int. 2016, 42, 8587-8596. [CrossRef]

51. Liu, Y.; Xiang, M.; Hong, L. Three-dimensional nitrogen and boron codoped graphene for carbon dioxide and oils adsorption. RSC Adv. 2017, 7, 6467-6473. [CrossRef]

52. Bhanja, P.; Das, S.K.; Patra, A.K.; Bhaumik, A. Functionalized graphene oxide as an efficient adsorbent for $\mathrm{CO}_{2}$ capture and support for heterogeneous catalysis. RSC Adv. 2016, 6, 72055-72068. [CrossRef]

53. Politakos, N.; Barbarin, I.; Cantador, L.S.; Cecilia, J.A.; Mehravar, E.; Tomovska, R. Graphene-based Monolithic Nanostructures for $\mathrm{CO}_{2}$ Capture. Ind. Eng. Chem. Res. 2020, 59, 8612-8621. [CrossRef]

54. Huang, A.; Feng, B. Facile synthesis of PEI-GO@ ZIF-8 hybrid material for $\mathrm{CO}_{2}$ capture. Int. J. Hydrog. Energy 2018, 43, 2224-2231. [CrossRef]

55. Rahimi, M.; Babu, D.J.; Singh, J.K.; Yang, Y.B.; Schneider, J.J.; Müller-Plathe, F. Double-walled carbon nanotube array for $\mathrm{CO}_{2}$ and $\mathrm{SO}_{2}$ adsorption. J. Chem. Phys. 2015, 143, 124701. [CrossRef] [PubMed]

56. Zhao, W.; Bai, J.; Francisco, J.S.; Zeng, X.C. Formation of $\mathrm{CO}_{2}$ hydrates within single-walled carbon nanotubes at ambient pressure: $\mathrm{CO}_{2}$ capture and selective separation of $\mathrm{CO}_{2} / \mathrm{H}_{2}$ mixture in water. J. Phys. Chem. 2018, 122, 7951-7958. [CrossRef]

57. Cortés-Súarez, J.; Celis-Arias, V.; Beltrán, H.I.; Tejeda-Cruz, A.; Ibarra, I.A.; Romero-Ibarra, J.E.; Sánchez-González, E.; Loera-Serna, S. Synthesis and characterization of an SWCNT@ HKUST-1 composite: Enhancing the $\mathrm{CO}_{2}$ adsorption properties of HKUST-1. ACS Omega 2019, 4, 5275-5282. [CrossRef]

58. Kemp, K.C.; Chandra, V.; Saleh, M.; Kim, K.S. Reversible $\mathrm{CO}_{2}$ adsorption by an activated nitrogen doped graphene/polyaniline material. Nanotechnology 2013, 24, 235703. [CrossRef]

59. Shin, G.J.; Rhee, K.; Park, S.J. Improvement of $\mathrm{CO}_{2}$ capture by graphite oxide in presence of polyethylenimine. Int. J. Hydrog. Energy 2016, 41, 14351-14359. [CrossRef]

60. Deng, M.; Park, H.G. Spacer-assisted amine-coiled carbon nanotubes for $\mathrm{CO}_{2}$ capture. Langmuir 2019, 35, 4453-4459. [CrossRef]

61. Gromov, A.; Kulur, A.; Gibson, J.; Mangano, E.; Brandani, S.; Campbell, E. Carbon nanotube/PVA aerogels impregnated with PEI: Solid adsorbents for $\mathrm{CO}_{2}$ capture. Sustain. Energy Fuels 2018, 2, 1630-1640. [CrossRef]

62. Alhwaige, A.A.; Agag, T.; Ishida, H.; Qutubuddin, S. Biobased chitosan hybrid aerogels with superior adsorption: Role of graphene oxide in $\mathrm{CO}_{2}$ capture. RSC Adv. 2013, 3, 16011-16020. [CrossRef]

63. Alhwaige, A.A.; Ishida, H.; Qutubuddin, S. Carbon aerogels with excellent $\mathrm{CO}_{2}$ adsorption capacity synthesized from clay-reinforced biobased chitosan-polybenzoxazine nanocomposites. ACS Sustain. Chem. Eng. 2016, 4, 1286-1295. [CrossRef] 
64. Sircar, S.; Golden, T.C.; Rao, M.B. Activated carbon for gas separation and storage. Carbon 1996, 3, 1-12. [CrossRef]

65. Hayashi, J.; Kazehaya, A.; Muroyama, K.; Watkinson, A.P. Preparation of activated carbon from lignin by chemical activation. Carbon 2000, 38, 1873-1878. [CrossRef]

66. Ge, C.; Lian, D.; Cui, S.; Gao, J.; Lu, J. Highly selective $\mathrm{CO}_{2}$ capture on waste polyurethane foam-based activated carbon. Processes 2019, 7, 592. [CrossRef]

67. Borhan, A.; Yusup, S.; Lim, J.W.; Show, P.L. Characterization and modelling studies of activated carbon produced from rubber-seed shell using $\mathrm{KOH}$ for $\mathrm{CO}_{2}$ adsorption. Processes 2019, 7, 855. [CrossRef]

68. Basheer, O.A.; Hanafiah, M.M.; Abdulhakim Alsaadi, M.; Al-Douri, Y.; Malek, M.A.; Mohammed Aljumaily, M.; Saadi Fiyadh, S. Synthesis and characterization of natural extracted precursor date palm fibre-based activated carbon for aluminum removal by RSM optimization. Processes 2019, 7, 249. [CrossRef]

69. Shao, X.; Feng, Z.; Xue, R.; Ma, C.; Wang, W.; Peng, X.; Cao, D. Adsorption of $\mathrm{CO}_{2}, \mathrm{CH}_{4}, \mathrm{CO}_{2} / \mathrm{N}_{2}$ and $\mathrm{CO}_{2} / \mathrm{CH}_{4}$ in novel activated carbon beads: Preparation, measurements and simulation. AIChE J. 2011, 57, 3042-3051. [CrossRef]

70. Chen, J.; Yang, J.; Hu, G.; Hu, X.; Li, Z.; Shen, S.; Radosz, M.; Fan, M. Enhanced $\mathrm{CO}_{2}$ capture capacity of nitrogen-doped biomass-derived porous carbons. ACS Sustain. Chem. Eng. 2016, 4, 1439-1445. [CrossRef]

71. Li, Y.; $\mathrm{Li}$, D.; Rao, Y.; Zhao, X.; Wu, M. Superior $\mathrm{CO}_{2}, \mathrm{CH}_{4}$, and $\mathrm{H}_{2}$ uptakes over ultrahigh-surface-area carbon spheres prepared from sustainable biomass-derived char by $\mathrm{CO}_{2}$ activation. Carbon 2016, 105, 454-462. [CrossRef]

72. Chiang, Y.C.; Yeh, C.Y.; Weng, C.H. Carbon Dioxide Adsorption on Porous and Functionalized Activated Carbon Fibers. Appl. Sci. 2019, 9, 1977. [CrossRef]

73. Shi, W.; Wang, R.; Liu, H.; Chang, B.; Yang, B.; Zhang, Z. Biowaste-derived 3D honeycomb-like N and S dual-doped hierarchically porous carbons for high-efficient $\mathrm{CO}_{2}$ capture. RSC Adv. 2019, 9, 23241-23253. [CrossRef]

74. Wang, R.; Wang, P.; Yan, X.; Lang, J.; Peng, C.; Xue, Q. Promising porous carbon derived from celtuce leaves with outstanding supercapacitance and CO2 capture performance. ACS Appl. Mater. 2012, 4, 5800-5806. [CrossRef] [PubMed]

75. Wei, H.; Chen, H.; Fu, N.; Chen, J.; Lan, G.; Qian, W.; Liu, Y.; Lin, H.; Han, S. Excellent electrochemical properties and large $\mathrm{CO}_{2}$ capture of nitrogen-doped activated porous carbon synthesised from waste longan shells. Electrochim. Acta 2017, 231, 403-411. [CrossRef]

76. Ahmed, M.B.; Johir, M.A.H.; Zhou, J.L.; Ngo, H.H.; Nghiem, L.D.; Richardson, C.; Moni, M.A.; Bryant, M.R. Activated carbon preparation from biomass feedstock: Clean production and carbon dioxide adsorption. J. Clean. Prod. 2019, 225, 405-413. [CrossRef]

77. Ello, A.S.; de Souza, L.K.; Trokourey, A.; Jaroniec, M. Coconut shell-based microporous carbons for $\mathrm{CO}_{2}$ capture. Microporous Mesoporous Mater. 2013, 180, 280-283. [CrossRef]

78. Parshetti, G.K.; Chowdhury, S.; Balasubramanian, R. Biomass derived low-cost microporous adsorbents for efficient $\mathrm{CO}_{2}$ capture. Fuel 2015, 148, 246-254. [CrossRef]

79. Demir, M.; Tessema, T.D.; Farghaly, A.A.; Nyankson, E.; Saraswat, S.K.; Aksoy, B.; Islamoglu, T.; Collinson, M.M.; El-Kaderi, H.M.; Gupta, R.B. Lignin-derived heteroatom-doped porous carbons for supercapacitor and $\mathrm{CO}_{2}$ capture applications. Int. J. Energy Res. 2018, 42, 2686-2700. [CrossRef]

80. Yu, D.; Hu, J.; Zhou, L.; Li, J.; Tang, J.; Peng, C.; Liu, H. Nitrogen-doped coal tar pitch based microporous carbons with superior $\mathrm{CO}_{2}$ capture performance. Energy Fuels 2018, 32, 3726-3732. [CrossRef]

81. Shafeeyan, M.S.; Daud, W.M.A.W.; Houshmand, A.; Shamiri, A. A review on surface modification of activated carbon for carbon dioxide adsorption. J. Anal. Appl. Pyrolysis 2010, 89, 143-151. [CrossRef]

82. Petrova, B.; Budinova, T.; Petrov, N.; Yardim, M.; Ekinci, E.; Razvigorova, M. Effect of different oxidation treatments on the chemical structure and properties of commercial coal tar pitch. Carbon 2005, 43, 261-267. [CrossRef]

83. Zhang, X.Q.; Li, W.C.; Lu, A.H. Designed porous carbon materials for efficient $\mathrm{CO}_{2}$ adsorption and separation. New Carbon Mater. 2015, 30, 481-501. [CrossRef]

84. Long, L.; Jiang, X.; Liu, J.; Han, D.; Xiao, M.; Wang, S.; Meng, Y. In situ template synthesis of hierarchical porous carbon used for high performance lithium-sulfur batteries. RSC Adv. 2018, 8, 4503-4513. [CrossRef]

85. Cox, M.; Mokaya, R. Ultra-high surface area mesoporous carbons for colossal pre combustion $\mathrm{CO}_{2}$ capture and storage as materials for hydrogen purification. Sustain. Energy Fuels 2017, 1, 1414-1424. [CrossRef] 
86. Huang, K.; Chai, S.H.; Mayes, R.T.; Tan, S.; Jones, C.W.; Dai, S. Significantly increasing porosity of mesoporous carbon by $\mathrm{NaNH}_{2}$ activation for enhanced $\mathrm{CO}_{2}$ adsorption. Microporous Mesoporous Mater. 2016, 230, 100-108. [CrossRef]

87. Lu, J.; Jiao, C.; Majeed, Z.; Jiang, H. Magnesium and Nitrogen Co-Doped Mesoporous Carbon with Enhanced Microporosity for $\mathrm{CO}_{2}$ Adsorption. Nanomaterials 2018, 8, 275. [CrossRef]

88. Yaumi, A.; Bakar, M.A.; Hameed, B. Reusable nitrogen-doped mesoporous carbon adsorbent for carbon dioxide adsorption in fixed-bed. Energy 2017, 138, 776-784. [CrossRef]

89. Park, D.H.; Lakhi, K.S.; Ramadass, K.; Kim, M.K.; Talapaneni, S.N.; Joseph, S.; Ravon, U.; Al-Bahily, K.; Vinu, A. Energy efficient synthesis of ordered mesoporous carbon nitrides with a high nitrogen content and enhanced $\mathrm{CO}_{2}$ capture capacity. Chem. Eur. J. 2017, 23, 10753-10757. [CrossRef]

90. Pei, Y.R.; Choi, G.; Asahina, S.; Yang, J.H.; Vinu, A.; Choy, J.H. A novel geopolymer route to porous carbon: High $\mathrm{CO}_{2}$ adsorption capacity. Chem. Comm. 2019, 55, 3266-3269. [CrossRef]

91. Srinivas, G.; Krungleviciute, V.; Guo, Z.X.; Yildirim, T. Exceptional $\mathrm{CO}_{2}$ capture in a hierarchically porous carbon with simultaneous high surface area and pore volume. Energy Environ. Sci. 2014, 7, 335-342. [CrossRef]

92. Lu, A.H.; Hao, G.P.; Zhang, X.Q. Porous carbons for carbon dioxide capture. In Porous Materials for Carbon Dioxide Capture; Springer: Berlin, Germany, 2014; pp. 15-77.

93. Yuan, B.; Wu, X.; Chen, Y.; Huang, J.; Luo, H.; Deng, S. Adsorption of $\mathrm{CO}_{2}, \mathrm{CH}_{4}$, and $\mathrm{N}_{2}$ on ordered mesoporous carbon: Approach for greenhouse gases capture and biogas upgrading. Environ. Sci. Technol. 2013, 47, 5474-5480. [CrossRef]

94. Zhang, Z.; Luo, D.; Lui, G.; Li, G.; Jiang, G.; Cano, Z.P.; Deng, Y.P.; Du, X.; Yin, S.; Chen, Y. In-situ ion-activated carbon nanospheres with tunable ultramicroporosity for superior $\mathrm{CO}_{2}$ capture. Carbon 2019, 143, 531-541. [CrossRef]

95. Liu, L.; Zhang, H.; Wang, G.; Du, J.; Zhang, Y.; Fu, X.; Chen, A. Synthesis of mesoporous carbon nanospheres via "pyrolysis-deposition" strategy for $\mathrm{CO}_{2}$ capture. J. Mater. Sci. 2017, 52, 9640-9647. [CrossRef]

96. Zhou, J.; Li, Z.; Xing, W.; Zhu, T.; Shen, H.; Zhuo, S. N-doped microporous carbons derived from direct carbonization of $\mathrm{K}^{+}$exchanged meta-aminophenol-formaldehyde resin for superior $\mathrm{CO}_{2}$ sorption. Chem. Comm. 2015, 51, 4591-4594. [CrossRef]

97. Liu, Z.; Zhang, Z.; Jia, Z.; Zhao, L.; Zhang, T.; Xing, W.; Komarneni, S.; Subhan, F.; Yan, Z. New strategy to prepare ultramicroporous carbon by ionic activation for superior $\mathrm{CO}_{2}$ capture. Chem. Eng. J. 2018, 337, 290-299. [CrossRef]

98. Robertson, C.; Mokaya, R. Microporous activated carbon aerogels via a simple subcritical drying route for $\mathrm{CO}_{2}$ capture and hydrogen storage. Microporous Mesoporous Mater. 2013, 179, 151-156. [CrossRef]

99. Xing, W.; Liu, C.; Zhou, Z.; Zhang, L.; Zhou, J.; Zhuo, S.; Yan, Z.; Gao, H.; Wang, G.; Qiao, S.Z. Superior $\mathrm{CO}_{2}$ uptake of N-doped activated carbon through hydrogen-bonding interaction. Energy Environ. Sci. 2012, 5 , 7323-7327. [CrossRef]

100. Chang, B.; Sun, L.; Shi, W.; Zhang, S.; Yang, B. Cost-Efficient Strategy for Sustainable Cross-Linked Microporous Carbon Bead with Satisfactory $\mathrm{CO}_{2}$ Capture Capacity. ACS Omega 2018, 3, 5563-5573. [CrossRef]

101. Fan, X.; Zhang, L.; Zhang, G.; Shu, Z.; Shi, J. Chitosan derived nitrogen-doped microporous carbons for high performance $\mathrm{CO}_{2}$ capture. Carbon 2013, 61, 423-430. [CrossRef]

102. Manmuanpom, N.; Thubsuang, U.; Dubas, S.T.; Wongkasemjit, S.; Chaisuwan, T. Enhanced $\mathrm{CO}_{2}$ capturing over ultra-microporous carbon with nitrogen-active species prepared using one-step carbonization of polybenzoxazine for a sustainable environment. J. Environ. Manag. 2018, 223, 779-786. [CrossRef]

103. Seema, H.; Kemp, K.C.; Le, N.H.; Park, S.-W.; Chandra, V.; Lee, J.W.; Kim, K.S. Highly selective $\mathrm{CO}_{2}$ capture by S-doped microporous carbon materials. Carbon 2014, 66, 320-326. [CrossRef]

104. Hao, G.P.; Li, W.C.; Qian, D.; Lu, A.H. Rapid synthesis of nitrogen-doped porous carbon monolith for $\mathrm{CO}_{2}$ capture. Adv. Mater. 2010, 22, 853-857. [CrossRef]

105. Zhang, L.H.; Li, W.C.; Liu, H.; Wang, Q.G.; Tang, L.; Hu, Q.T.; Xu, W.J.; Qiao, W.H.; Lu, Z.Y.; Lu, A.H. Thermoregulated Phase-Transition Synthesis of Two-Dimensional Carbon Nanoplates Rich in sp ${ }^{2}$ Carbon and Unimodal Ultramicropores for Kinetic Gas Separation. Angew. Chem. Int. Ed. 2018, 57, 1632-1635. [CrossRef] 
106. Shen, W.; He, Y.; Zhang, S.; Li, J.; Fan, W. Yeast-based microporous carbon materials for carbon dioxide capture. ChemSusChem 2012, 5, 1274-1279. [CrossRef]

107. Guo, L.P.; Hu, Q.T.; Zhang, P.; Li, W.C.; Lu, A.H. Polyacrylonitrile-Derived Sponge-Like Micro/Macroporous Carbon for Selective $\mathrm{CO}_{2}$ Separation. Chem. Eur. J. 2018, 24, 8369-8374. [CrossRef]

108. Li, Q.; Yang, J.; Feng, D.; Wu, Z.; Wu, Q.; Park, S.S.; Ha, C.-S.; Zhao, D. Facile synthesis of porous carbon nitride spheres with hierarchical three-dimensional mesostructures for $\mathrm{CO}_{2}$ capture. Nano Res. 2010, 3, 632-642. [CrossRef]

109. Estevez, L.; Barpaga, D.; Zheng, J.; Sabale, S.; Patel, R.L.; Zhang, J.G.; McGrail, B.P.; Motkuri, R.K. Hierarchically porous carbon materials for $\mathrm{CO}_{2}$ capture: The role of pore structure. Ind. Eng. Chem. Res. 2018, 57, 1262-1268. [CrossRef]

110. Wang, Y.; Wang, J.; Ma, C.; Qiao, W.; Ling, L. Fabrication of hierarchical carbon nanosheet-based networks for physical and chemical adsorption of $\mathrm{CO}_{2}$. J. Colloid Interf. Sci. 2019, 534, 72-80. [CrossRef]

111. Chang, B.; Shi, W.; Yin, H.; Zhang, S.; Yang, B. Poplar catkin-derived self-templated synthesis of N-doped hierarchical porous carbon microtubes for effective $\mathrm{CO}_{2}$ capture. Chem. Eng. J. 2019, 358, 1507-1518. [CrossRef]

112. Li, Y.; Xu, R.; Wang, X.; Wang, B.; Cao, J.; Yang, J.; Wei, J. Waste wool derived nitrogen-doped hierarchical porous carbon for selective $\mathrm{CO}_{2}$ capture. RSC Adv. 2018, 8, 19818-19826. [CrossRef]

113. Gao, A.; Guo, N.; Yan, M.; Li, M.; Wang, F.; Yang, R. Hierarchical porous carbon activated by $\mathrm{CaCO}_{3}$ from pigskin collagen for $\mathrm{CO}_{2}$ and $\mathrm{H}_{2}$ adsorption. Microporous Mesoporous Mater. 2018, 260, 172-179. [CrossRef]

114. Marszewska, J.; Jaroniec, M. Tailoring porosity in carbon spheres for fast carbon dioxide adsorption. J. Colloid Interf. Sci. 2017, 487, 162-174. [CrossRef]

115. Ahmed, M.B.; Zhou, J.L.; Ngo, H.H.; Guo, W. Adsorptive removal of antibiotics from water and wastewater: Progress and challenges. Sci. Total Environ. 2015, 532, 112-126. [CrossRef]

116. Shi, X.; Xiao, H.; Liao, X.; Armstrong, M.; Chen, X.; Lackner, K.S. Humidity effect on ion behaviors of moisture-driven $\mathrm{CO}_{2}$ sorbents. J. Chem. Phys. 2018, 149, 164708. [CrossRef]

(C) 2020 by the authors. Licensee MDPI, Basel, Switzerland. This article is an open access article distributed under the terms and conditions of the Creative Commons Attribution (CC BY) license (http://creativecommons.org/licenses/by/4.0/). 